\title{
Impact of blood salvage during liver transplantation on reduction in transfusion requirements ${ }^{1}$
}

\section{Impacto do uso do cell saver na redução de transfusão sanguínea durante o transplante de fígado}

\author{
Ajith Kumar Sankarankutty ${ }^{2}$, Andreza Correa Teixeira ${ }^{3}$, Fernanda Fernandes Souza ${ }^{3}$, Enio David Mente ${ }^{4}$, Gustavo \\ Ribeiro de Oliveira ${ }^{4}$, Rachel Cristina Camargo Almeida ${ }^{5}$, Camila Marques de Andrade $^{5}$, Eliana Aparecida Lopes Origuella ${ }^{5}$, \\ Orlando de Castro e Silva ${ }^{6}$ \\ 1. Study performed in the Liver Transplantation Unit of Division of Gastroenterology of the Department of Surgery and Anatomy of \\ Ribeirão Preto Faculty of Medicine -University of São Paulo - (FMRP-USP), Brazil. \\ 2. PhD, Professor of Division of Gastroenterology of the Department $f$ Surgery and Anatomy. Operational coordinator of the Liver \\ Transplant Program, (FMRP-USP), Brazil. \\ 3. Fellow Master degree, Member of the Liver Transplant Program of the Division of Gastroenterology of the Department of Surgery and \\ Anatomy, (FMRP-USP), Brazil. \\ 4. PhD, Assistant of Division of Gastroenterology of the Department of Surgery and Anatomy, (FMRP-USP), Brazil. \\ 5. Clinical Perfusion Scientist of the Liver Transplant Program, (FMRP-USP), Brazil. \\ 6. Full Professor, Head of Division of Gastroenterology of the Department of Surgery and Anatomy, Coordinator of the Liver Transplant \\ Program, (FMRP-USP), Brazil.
}

\begin{abstract}
Purpose: The aim of this study was to analyse the changes in transfusion requirements, in patients submitted to orthotopic liver transpantation from cadaveric donors, with the use of intraoperative red blood cell salvage (Cell Saver). Methods: Data from 41 transplants were analysed. Intraoperative blood loss was calculated from the cell salvage, suction and the swabs. The autologous and heterologous transfusions were recorded The red blood salvage was performed using the Cell Saver 5 System (Haemonetics).. For analysis the patients were divided in two groups: one that used the Cell Saver and another that didn't. Results: The median age of the patients was 50 years and the main indication for liver transplantation was cirrhosis (35 cases - 85.3\%). The median blood loss was $8362 \pm 3994 \mathrm{ml}$ (with the Cell Saver) and $10824 \pm 7002 \mathrm{ml}$ (without the Cell Saver) and the median transfusion of heterologous packed red blood cells was 9,6 \pm 8 units (with the Cell Saver) compared to $22,3 \pm 21$ units (without the Cell Saver). Conclusions: The Cells Saver has the potential to reduce the need for heterologous blood transfusion reducing the risks of transmissible diseases.
\end{abstract}

Key words: Liver Transplantation. Cell Saver. Blood Transfusion. Liver Surgery.

\section{RESUMO}

Objetivo: O objetivo desse estudo foi analisar as mundanças na quantidade de transfusão necessária com uso do Intraoperative red blood cell salvage (Cell saver), em pacientes submetidos a transplante ortotópico de fígado, doador cadáver. Métodos: Foram avaliados dados de 41 pacientes submetidos a transplante de fígado. O sangramento foi calculado de acordo com débito do aspirador, compressas e captação do Cell saver. A reposição necessária foi avaliada de acordo com a quantidade de transfusão heteróloga e autóloga. Para análise dos dados os pacientes foram dividos em dois grupos: com e sem uso de Cell saver. Resultados: A mediana de idade foi 50 anos e principal indicação de transplante foi cirrose hepática com 35 casos (85,3\%). A mediana de sangramento durante o procedimento cirúrgico $8362 \pm 3994 \mathrm{ml}$ (com cell saver) e $10824 \pm 7002 \mathrm{ml}$ (sem cell saver) e a mediana de transfusão de concentrado de hemácias heterólogo, durante o período de internação hospitalar 9,6 \pm 8 unidades (com cell saver) compar 22,3 \pm 21 unidades (sem cell saver). Conclusão: Uso de Cell Saver tem um potential para reduzir a quantidade de transfusão heteróloga, dimuindo o risco de transmissão de doenças.

Descritores: Transplante Hepático. Cell Saver. Transfusão de Sangue. Cirurgia Hepática. 


\section{Introduction}

Liver transplantation is associated with significant use of allogenic blood products, which places considerable demands on finite resources and increases recipient exposure to viral, bacterial and protozoal diseases associated with transfusion, undesirable events in immunosuppressed patients ${ }^{1}$. Intraoperative bleeding and homologous transfusions, during liver transplantation, are associated with increased postoperative morbidity and mortality in the recepients ${ }^{2}$. During this procedure, abnormal bleeding typically occurs as a consequence of hemostatic dysfunction and portal hypertension, in addition to the surgery itself. The etiology of the abnormalities of hemostasis is multifactorial, including deficit in platelets, coagulation factors related to the existing liver disease and increased fibrinolysis ${ }^{3}$. Lack of t-PA clearance during the anhepatic phase allied to the burst release of t-PA associated with the reperfusion of the ischemic graft result in great amounts of circulating tissue-type plasminogen activator (t-PA), with the consequent pathological activation of the fibrinolytic system ${ }^{3}$. Intraoperative red blood cell salvage (IRCBS) and autologous transfusion is not routinely used as cost effectiveness is a major concern ${ }^{1}$. The aim of this study was to analyse the changes in the transfusion requirements with the routine use of intraoperative red blood cell salvage.

\section{Methods}

Between April 2001 and May 2006, 46 adult liver transplants, with cadaveric donors, were undertaken at this center. The "piggy back" technique was utilized in all patients. During this time period, no transplants were performed for a year and a half due to administrative problems. Initially, for the first 16 transplants, intraoperative blood salvage was not available due to the lack of necessary equipment. Once available, it was routinely utilized in every procedure, except in situations which were considered contraindications. In this group of patients, sepsis and hepatocellular carcinoma were considered absolute contraindications for the use of intraoperative cell salvage. Aprotinin was available for all patients. When used, it was administered generally in the following dose: $0.5 \times 10^{6}$ units in the first hour, followed by $0.2 \times 10^{6}$ units/hour for the remaining period. Infusion was started prophylatically before incision and continued till 2 hours after perfusion of the graft. Intraoperative bleeding was calculated from the cell salvage, suction and the swabs. The total amount of blood salvaged, processed and transfused was also recorded, along with the quantity of heterologous blood utilized. The red blood salvage was performed using the Cell Saver 5 System (Haemonetics). In the postoperative period, transfusion practice was conservative, refraining from transfusing platelets or fresh frozen plasma even with values as low as 16000 cells $/ \mathrm{mm}^{3}$ and 3.5 (INR), respectively, unless there were signs of bleeding. Lowest acceptable level for postoperative hemoglobin was considered $8 \mathrm{~g} / \mathrm{dl}$, below which transfusion was recommended. This is a discriptive study as the small number of patients did not allow a meaningfull statistical analysis.

\section{Results}

The median age of the patients was 50 years (range, 26 to 66). Five procedures were excluded from the analysis due to incomplete data. Data from the remaining 41 patients were included. The reasons for liver transplantation are shown in Table 1. Of the 41 transplants, $35(85.3 \%)$ were for chronic liver disease, 2 (4.9\%) for acute liver failure, 2 (4.9\%) retransplants and $2(4.9 \%)$ patients had Familial Amyloidotic Polyneuropathy. All the transplant procedures were performed using the "piggyback" technique.

TABLE 1 - Causes of hepatic disease and liver transplantation, and distribution of the patients according to the use of IRBCS

\begin{tabular}{lcc}
\hline $\begin{array}{l}\text { Cause hepatic } \\
\text { disease and liver } \\
\text { transplantation }\end{array}$ & $\begin{array}{l}\text { IRBCS } \\
\text { utilized }\end{array}$ & $\begin{array}{c}\text { IRBCS } \\
\text { not } \text { utilized }\end{array}$ \\
\hline Alcohol & 6 & 7 \\
HCV & 4 & 7 \\
Criptogenic & 3 & 2 \\
HBV & 3 & 0 \\
Autoimmune hepatitis & 3 & 0 \\
Acute liver failure & 1 & 1 \\
Re-transplant & 0 & 2 \\
FAP & 2 & 0 \\
\hline Total & $\mathbf{2 2}$ & $\mathbf{1 9}$ \\
\hline
\end{tabular}

IRBCS - intraoperative red blood cell salvage; HCC - hepatocellular carcinoma; HBV - hepatitis B virus; HCV - hepatitis C virus; FAP Familial amyloidótic polyneuropathy

Though the small number of patients does not allow significant statistical analysis, it offers an opportunity for reflection on the utilization of intraoperative red blood cell salvage and transfusion practise. Transfusion requirements showed great variation. Distribution of patient characteristics, surgical data and transfusion of blood components according to the utilization or not of IRBCS is shown in Table 2. According to the Child-Turcotte-Pugh classification the patients were distributed in the following manner: respectively Child $\mathrm{A} / \mathrm{B} / \mathrm{C}$ 2/13/5 (using IRBCS) and 3/10/3 (not using IRBCS). The median Model End Liver Disease (MELD) score for those patients in whom IRBCS was used was $15.1 \pm 4.99$ and $14.9 \pm 4.3$ in whom it wasn't. The surgical procedure had a median duration of 603 $\pm 94 \mathrm{~min}$, in the group using IRBCS, and $671 \pm 117 \mathrm{~min}$ in the other group. The median amount of blood lost during the procedure was $8362 \pm 3994 \mathrm{ml}$ (using IRBCS) and $10824 \pm 7002$ $\mathrm{ml}$ (not using IRBCS). The median amount of blood salvaged for autologous transfusion was $5074 \pm 3055 \mathrm{ml}$, of which 4063 $\pm 2554 \mathrm{ml}$ was processed for utilization. In the group of patients using IRBCS, the median units of heterologous packed red blood cells transfused, during the entire period of hospitalization, was $9,6 \pm 8$ compared to $22,3 \pm 21$ in the group not using IRBCS. Regarding fresh frozen plasma, 10,2 $\pm 12,7$ units (using IRBCS) were transfused compared to $23,8 \pm 23,8$ units (not using IRBCS). Similar data regarding platelet transfusion was respectively, 9,6 $\pm 12,3$ units (using IRBCS) compared to $12,5 \pm 15,9$ units (not using IRBCS). 
TABLE 2 - Distribution of patient characteristics, surgical data and transfusion of blood components according to the utilization or not of intraoperative red blood cell salvage.

\begin{tabular}{lll}
\hline Patients characteristics & IRBCS utilized & IRBCS not utilized \\
\hline Male/Female & $14 / 8$ & $17 / 2$ \\
Age (years) & $45 \pm 11,4$ & $51,8 \pm 9,4$ \\
MELD & $15,1 \pm 4,99$ & $14,9 \pm 4,3$ \\
Total blood loss & $8362 \pm 3994 \mathrm{ml}$ & $10824 \pm 7002 \mathrm{ml}$ \\
Blood salvage & $5074 \pm 3055 \mathrm{ml}$ & \\
Autologous transfusion & $4063 \pm 2554 \mathrm{ml}$ & \\
Opertive time & $603 \pm 94$ min & $671 \pm 117$ min \\
Packed red blood cells & $9,6 \pm 8$ units & $22,3 \pm 21$ units \\
Platelet concentrates & $9,6 \pm 12,3$ units & $12,5 \pm 15,9$ units \\
Fresh frozen plasma & $10,2 \pm 12,7$ units & $23,8 \pm 23,8$ units \\
\hline
\end{tabular}

IRBCS - intraoperative red blood cell salvage; MELD - Model End Liver Disease

\section{Discussion}

Although the number of patients is small for significant statistical analysis, this study gives us an important opportunity to evaluate the transfusion practice and strategies employed in liver transplantation. Most of the patients in both groups were of class Child $B$, with a median MELD score of $15.1 \pm 4.99$, in whom the IRBCS was used, and $14.9 \pm 4.3$, in whom it was not. The patients had cirrhosis predominantly of moderate severity. This probably reflects the chronological criterion utilized in Brazil for the allocation of cadaveric liver for transplantation. While any criteria utilized will have its own advantages and disadvantages, this criterion has implied in a 2 to 3 years wait for a cadaveric organ. The present legislation, soon to be implemented, utilizes the MELD score for allocating organs. This will have its repercussion on the transplant procedure, possibly with greater transfusion requirements, an extra load on finite resources, as patients with more severe disease and less physiologic reserve will be operated on. Therefore the present analysis is pertinent in the scenario. The median duration of the surgical procedure was less in the group which used IRBCS, an average of 68 minutes less. This coincides with the experience gained by the surgical team. Due to the lack of equipment, IRBCS was routinely used only after the first 17 cases, a period by which the team had accumulated technical expertise. The blood loss during the surgery also reflects this technical refinement, with less intraoperative blood loss in the group which used IRBCS $(8362 \pm 3994 \mathrm{ml}$ versus $10824 \pm 7002 \mathrm{ml})$. When IRBCS was used, more than half of the blood lost was recovered (5074 \pm 3055 $\mathrm{ml}$ ) and this was almost entirely available for reinfusion $(4063 \pm 2554 \mathrm{ml})$, after processing. The considerable reduction in heterologous red blood cell transfusion requirement, in the group which used IRBCS $(9,6 \pm 8$ units versus $22,3 \pm 21$ units), is due in part to the possibility of utilizing this blood which would otherwise be lost in the operative field. Substantial reduction in fresh frozen plasma transfusion and a lesser reduction in platelet requirement was also seen in the IRBCS group. Technical refinements, noted earlier, are also partly responsible for the reduction in heterologous transfusion requirements. Though significant statistical studies could not be performed, there does seem to be a definite tendency towards reduced transfusion requirements with the use of IRBCS. The presence of hepatocellularcarcinoma was considered a contraindication for the use of IRBCS due to the theoretical risk of reintroducing neoplastic cells into the circulation. Though a recent study did not detect any difference in the incidence of neoplastic recurrence with the use of IRBCS this remains a concern and needs to be confirmed ${ }^{4}$. Perhaps in the future, the use of IRBCS can be extended to patients with hepatocellularcarcinoma. Though donor-specific blood transfusion has been proposed, as a means to achieve tolerance through the development of microchimerism, especially for kidney transplants, it's place in liver transplantation is not yet defined, especially with the development of new immunosuppressants and better rejection management ${ }^{5}$. Therefore any strategy that reduces the demand for heterologous transfusion is welcome as it reduces exposure to transmissible infectious diseases, viral, bacterial and protozoan ${ }^{6}$. Among the methods used to reduce the blood loss during liver transplant is the use of bolus recombinant activated factor VII (rFVIIa). Two recent retrospective studies obtained favorable results with reduced transfusion of packed red blood cells and fresh frozen plasma in the patients treated with $\mathrm{rFVIIa}^{7,8}$. Another method involves the use of antifibrinolytic agents with the intent of reducing intraoperative bleeding, caused by the huge amounts of circulating tPA during the anhepatic phase and the burst release of tPA associated with the reperfusion of the ischemic graft. Aprotinin has been shown to reduce transfusion requirements in surgeries with significant blood loss 9 . While a recent study comparing the effects of aprotinin and tranexamic acid on blood loss and transfusion requirements during liver transplantation showed that 
both drugs were equivalent in this regard ${ }^{3}$. Routine use of thromboelastography in the surgical theatre is another means to reduce transfusion of blood components, especially fresh frozen plasma and platelets. This measure has been noted to reduce transfusion in cardiac surgery and liver transplantation with a consequent reduction in surgical costs ${ }^{10}$. Of the various methods tried, probably the most radical is the complete avoidance of transfusion in certain extreme conditions, such as liver transplantation in Jehovah's witnesses. Successful preoperative erythropoeitin therapy, iron and folic acid supplementation, partial spleen embolization, allied to the utilization of continuous circuit cell saving system and high dose aprotinin in such situations have been reported $^{11}$. In this study, as in other reports, the use of IRBCS shows a tendency to reduce transfusion of blood components. In a prospective study published recently, the use of IRBCS was shown not only to reduce transfusion but also could be cost effective ${ }^{1}$. In summary, IRBCS has the potential to reduce the need for heterologous transfusion, thereby reducing the risks disease transmission and allied to this could even bring about cost reduction. If all the methods available for reducing transfusion were to be utilized, liver transplantation could possibly be a safer and less costly procedure.

\section{References}

1. Phillips SD, Deshpande R, Muiesan P, Bowles MJ, Rela $\mathrm{M}$, Heaton ND. A Prospective Study Investigating the Cost Effectiveness of Intraoperative Blood Salvage during Liver Transplantation. Transplantation. 2006; 81:536-40.

2. Cacciarelli TV, Keeffe EB, Moore DH, Cox KL, Berquist WE, Concepcion W, Hammer GB, So SK. Effect of Intraoperative Blood Transfusion on Patient Outcome in Liver Transplantation. Arch Surg. 1999; 134:25-9.
3. Ickx BE, Van der Linden PJ, Melot C, Wijns W, de Pauw L, Vandestadt J, Hut F, Pradier O. Comparison of the Effects of Aprotinin and Tranexamic Acid on Blood Loss and Red Blood Cell transfusion Requirements during the Late Stages of Liver Transplantation. Transfusion. 2006;46:595-605.

4. Muscari F, Suc B, Vigouroux D, Duffas JP, Migueres I, Mathieu A, Lavayssiere L, Rostaing L, Fourtanier G. Blood Salvage Autotransfusion during Transplantation for Hepatocarcinoma: does it increase the risk of neoplastic recurrence? Transplant Int. 2005; 18:1236-9.

5. Siemionow MAG. Role of Blood Transfusion in Transplantation: a Review. J Reconst Microsurg. 2005; 21:555-63.

6. Chamberland ME. Emerging infectious agents: do they pose a risk to the safety of transfused blood and blood products? Clin Inf Dis. 2002; 34:797-805.

7. Kalicinski P, Markiewicz M, Kaminski A, Laniewski P, Ismail H, Drewniak T, Szymczak M, Nachulewicz P, Jezierska E. Single pretransplant bolus of recombinant activated factor VII ameliorates influence of risk factors for blood loss during orthotopic liver transplantation. Ped Transpl. 2005;9:299-304.

8. Niemann CU, Behrends M, Quan D, Eilers H, Gropper MA, Roberts JP, Hirose R. Recombinant factor VIIa reduces transfusion requirements in liver transplant patients with high MELD scores. Transf Med. 2006; 16:93-100.

9. Lentschener C, Roche K, Ozier Y. A review of aprotinin in orthotopic liver transplantation: can its harmful effects offset its beneficial effects? Anesth Analg. 2005; 100:1248-55.

10. Sorensen ER, Lorme TB, Heath D. Thromboelastography: a means to transfusion reduction. Nurs Manage. 2005; 36:27-34.

11. Detry O, Roover AD, Delwaide J, Kaba A, Joris J, Damas P, Lamy M, Honoré P, Meurisse M. Liver Transplantation in Jehovah's Witness. Transplant Int. 2005; 18:929-36.

\section{Correspondence:}

Orlando de Castro e Silva Jr.

Rua Campos Salles, 809 - $9^{\circ}$ andar. CEP: 14015-110

Centro, Ribeirão Preto - SP - Brazil.

Email: orlando@,fmrp.usp.br
Conflict of interest: none Financial source: CNPq and FAPESP

\section{How to cite this article}

Sankarankutty AK, Teixeira AC, Souza FF, Mente ED, Oliveira GR, Almeida RCC, Andrade CM, Origuella LEA, Castro e Silva O. Impact of blood salvage during liver transplantation on reduction in transfusion requirements. Acta Cir Bras. [serial on the Internet] 2006;21 Suppl 1. Available from URL: http://www.scielo.br/acb 